\title{
ANALISIS KINERJA RUAS JALAN AKIBAT PARKIR PADA BADAN JALAN (STUDI KASUS : JALAN INDRAGIRI DEPAN SUPERMARKET PAGAR ALAM SQUARE)
}

\author{
Ahmad Syukarman ${ }^{1)}$, Indra Syahrul Fuad ${ }^{2)}$, Melinda Sriwahyuni ${ }^{3)}$ \\ Mahasiswa Sekolah Tinggi Teknologi Pagar Alam ${ }^{1)}$ \\ Dosen Sekolah Tinggi Teknologi Pagar Alam ${ }^{2-3)}$ \\ e-mail : melly_linda@ymail.com
}

\begin{abstract}
Abstrak : Kinerja jalan di Jalan Indragiri Kota Pagar Alam kurang berfungsi maksimal akibat adanya parkir pada bahu jalan. Penelitian ini dilakukan untuk menganalisis besar kapasitas jalan dan derajat kejenuhan terhadap volume kendaraan. Metode penelitian menggunakan perhitungan mengenai jumlah volume kendaraan yang melalui ruas jalan tersebut, kecepatan tempuh dan derajat kejenuhan, baru setelah itu membandingkan data yang ada dengan Standar MKJI untukmengukur Tingkat Pelayanan Jalan (Level Of Service).Hasil analisis Kapasitas dasar yang diperoleh ditentukan berdasarkan jumlah lajur dan jumlah jalur jalan Indragiri merupakan jalan 2 lajur 2 arah tak terbagi dengan kapastias dasar $(\mathrm{C} 0)=2900 \mathrm{smp} / \mathrm{jam}$ total dua arah.Derajat kejenuhan tinggi terjadi pada saat volume meningkat dilihat pada hari kerja yaitu hari Senin dan hari kamis, sedangkan hari libur yaitu hari Minggu terjadi penurunan angka derajat kejenuhan, serta kapasitas ruas jalan berkurang dikarenakan adanya badan jalan yang difungsikan sebagai area parkir.
\end{abstract}

Kata kunci : kinerja, ruas jalan, tingkat pelayanan

\begin{abstract}
Road performance at Indragiri Streetin Pagar Alam City dontfunctioning maximally, due to the parking on the park of road. The research was conducted to analyze the capacity of road and degree of saturation to vehicle volume. The research method uses the calculation of the volume of vehicles passing through the road, the speed of travel and the degree of saturation, and then comparing the existing data with the MKJI Standard to measure the Level of Service. Result of analysis is capacity obtained determined based on the number of lanes and the number at Indragiri street lanes is an indivisible 2 lane 2-way road with the base cotton $(\mathrm{C} 0)=2900$ $\mathrm{smp} /$ hour total of two directions. The degree of high saturation occurs when the volume increases on the weekdays is Monday and Thursday, while the weekend is on Sundays there is a decrease in the degree of saturation level, as well as reduced road capacity due to the existence of the road that functioned as a parking area.
\end{abstract}

Keywords : performance, part of road, level of service

\section{PENDAHULUAN}

Perkembanganaksesibilitas dapat meningkatkanpertumbuhan perekonomian daerah sehingga kebutuhan aksesibilitas sangat diperlukan dalam pembangunan daerah. Salah satu pusat ekonomi Kota Pagar Alam adalah Supermarket PagarAlam Square.Lokasi ini merupakan tempat jual beli dekat Pasar Induk Kota, sehingga terjadi kegiatan transaksi jual beli antara penjual dengan konsumen, dalam praktiknya membutuhkan suatu akses bagi para konsumen untuk dapat ke tempat
tersebut.Akses yang diperlukan yaitu jalan yang digunakan untuk keluar masuk area PagarAlam Square dan juga sebagai sarana lalu lintas kendaraan ke tempat lainnya.

Dengan adanya kendaraan-kendaraan yang diparkir dipinggiran jalan, akan dapat menimbulkan terjadinya antrian kendaraan bahkan kemacetan lalu lintas pada suatu ruas jalan. Ditambah lagi adanya kendaraan angkutan umum ataupun angkutan barang yang sedang menaikkan dan menurunkan muatannya. Hal itu, jelas sangat mengganggu 
kendaraan lain karena menghalangi jalan dan menghabiskan ruang gerak kendaraan lain. Pada ruas jalan tersebut digunakan sebagai tempat parkir kendaraan roda empat dan roda dua. Dengan kondisi seperti ini, maka kecepatan kendaraan yang lewat menjadi rendah dan jalan tidak dapat berfungsi secara maksimal. Dengan ini, maka Rumusan masalah dalam penelitian yaitu "bagaimana kemampuan kinerja Jalan IndragiridepanPagaralam Square terhadap besar kapasitas jalan akibat kendaraan parkir pada badan jalan dan derajat kejenuhan jalan terhadap volume kendaraan yang melalui ruas jalan?".

Tujuan penelitian ini adalah untuk mengetahuidanmenganalisis besar kapasitas jalan akibat kendaraan parkir pada badan jalan dan derajat kejenuhan jalan terhadap volume kendaraan yang melalui ruas jalan tersebut.Penelitianini,dapatmenjaditolakukur bagi pemerintah, sebagai saran untuk mengatasi masalah lalu lintas (kemacetan). Bagi masyarakat, diharapkan mendapatkan kenyamanan dan tidak terganggu dalam mengendarai kendaraan di Jalan Indragiri.

\section{METODE PENELITIAN}

Penelitian akan dilakukan di Jalan Indragiri tepatnya didepan Supermarket Pagaralam SquareKota Pagar Alam dan dilaksanakan pada bulan Agustus 2014. Penelitian dilakukan pada pukul 07.00 sampaipukul 18.00 selama 3 hari.

Data lapangan berupa data geometrik jalan seperti tipe jalan, jumlah jalur dan jumlah lajur jalan, lebar jalan, lebar jalan efektif, lebar bahu jalan, volume parkir, juga ada tidaknya median jalan. Sedangkan Data sekunder meliputi tabel dan rumus untuk mengalisis kinerja jalan berdasarkan MKJI dan jumlah penduduk Kota Pagar Alam. Analisis perhitunganyang digunakan jumlah volume kendaraan yang melalui ruas jalan tersebut, kecepatan tempuh dan derajat kejenuhan, membandingkan data yang adadenganStandar MKJI untukmengukur Tingkat Pelayanan Jalan (Level Of Service).

\subsection{Karakteristik Geometrik}

Karakteristik geometrik jalan terdiri dari tipe jalan, jalur lalu lintas, bahu jalan, trotoar dan kerb, serta median jalan. Tipe jalan ditunjukkan dengan potongan melintang jalan yang ditunjukkan oleh jumlah lajur dan arah pada setiap segmen jalan (MKJI, 1997).Menurut Sukirman (1994), Jalur lalu lintas adalah keseluruhan bagian perkerasan jalan yang diperuntukkan untuk lalu lintas kendaraan. Jalur lalu lintas terdiri dari beberapa lajur (lane) kendaraan. Lajur lalu lintas yaitu bagian dari jalur lalu lintas yang khusus diperuntukkan untuk dilewati oleh satu rangkaian kendaraan dalam satu arah. Lebar jalur lalu lintas merupakan bagian jalan yang paling menentukan lebar melintang jalan secara keseluruhan. Besarnya lebar jalur lalu lintas hanya dapat ditentukan dengan pengamatan langsung di lapangan.

Bahu jalan adalah jalur yang terletak berdampingan dengan jalur lalu lintas. (Sukirman, 1994) sedangkan trotoar adalah jalur yang terletak berdampingan dengan jalur lalu lintas yang khusus dipergunakan untuk pejalan kaki, serta kerb adalah penonjolan/peninggian tepi perkerasan atau bahu jalan yang dimaksudkan untuk keperluan drainase, mencegah keluarnya kendaraan dari tepi perkerasan dan memberikan ketegasan tepi perkerasan.Median jalan adalah jalur yang terletak di tengah jalan untuk membagi jalandalam masing-masing arah.

\subsection{Kinerja Jalan}

Tingkat kinerja jalan berdasarkan MKJI 1997 adalah ukuran kuantitatif yang menerangkan kondisi operasional. Nilai kuantitatif dinyatakan dalam kapasitas, derajat kejenuhan, derajat iringan, kecepatan rata-rata, waktu tempuh, tundaan, dan rasio kendaraan berhenti. Ukuran kualitatif yang menerangkan kondisi operasional dalam arus lalu lintas dan persepsi pengemudi tentang kualitas berkendaraan dinyatakan dengan tingkat pelayanan jalan.

a. Kapasitas

Kapasitas dasar ditentukan dengan persamaan dasar sebagai berikut :

$$
C=C_{O} \cdot F C_{W} \cdot F C_{S P} \cdot F C_{S F} \cdot F C_{C S}
$$


dengan :

$\mathrm{C}=$ Kapasitas (smp/jam)

$\mathrm{C}_{\mathrm{O}} \quad=$ Kapasitas dasar (smp/jam)

$\mathrm{FCW}=$ Faktor penyesuaian lebar jalan

FCSP = Faktor penyesuaian pemisah arah (hanya untuk jalan tak terbagi)

FCSF = Faktor penyesuaian hambatan samping dan bahu jalan

FCCS $=$ Faktor penyesuaian ukuran kota

Kapasitas segmen jalan pada kondisi geometri, ditentukan berdasarkan tipe jalan.

Tabel1. KapasitasDasar $\left(\mathrm{C}_{\mathrm{O}}\right)$ JalanPerkotaan

\begin{tabular}{|l|c|c|}
\hline \multicolumn{1}{|c|}{ Tipejalan } & $\begin{array}{c}\text { Kapasitasdasar } \\
(\mathrm{smp} / \mathrm{jam})\end{array}$ & Catatan \\
\hline $\begin{array}{l}\text { Empat-lajur terbagi } \\
\text { atau Jalan satu-arah }\end{array}$ & 1650 & Per lajur \\
\hline $\begin{array}{l}\text { Empat-lajur tak- } \\
\text { terbagi }\end{array}$ & 1500 & Per lajur \\
\hline Dua-lajur tak-terbagi & 2900 & $\begin{array}{c}\text { Total dua } \\
\text { arah }\end{array}$ \\
\hline
\end{tabular}

Faktor penyesuaian lebar jalan ditentukan berdasarkan lebar jalan efektif yang dapat dilihat pada Tabel berikut Tabel2.

FaktorPenyesuaianKapasitasAkibatLebarJ alan $(\mathrm{FCw})$

\begin{tabular}{|l|c|c|}
\hline \multicolumn{1}{|c|}{ Tipe } & $\begin{array}{c}\text { Jalan Lebar efektif } \\
\text { jalur lalu-lintas } \\
(\mathrm{Wc})(\mathrm{m})\end{array}$ & $\mathrm{FCW}$ \\
\hline Empat-lajur & Per lajur & \\
terbagi atau & 3,00 & 0,92 \\
Jalan satu-arah & 3,25 & 0,96 \\
& 3,50 & 1,00 \\
& 3,75 & 1,04 \\
Empat-lajur tak- & 4,00 & 1,08 \\
terbagi & Per lajur & \\
& 3,00 & 0,91 \\
& 3,25 & 0,95 \\
& 3,50 & 1,00 \\
& 3,75 & 1,05 \\
& 4,00 & 1,09 \\
\hline Dua-lajur tak- & Total kedua arah & \\
terbagi & 5 & 0,56 \\
& 6 & 0,87 \\
& 7 & 1,00 \\
& 8 & 1,14 \\
& 9 & 1,25 \\
& 10 & 1,29 \\
& 11,34 \\
\hline
\end{tabular}

Sumber: MKJI, 1997

Faktor penyesuaian pembagian arah jalan didasarkan pada kondisi dan distribusi arus lalu lintas dari kedua arah jalan atau untuk tipe jalan tanpa pembatas median.Untuk jalan satu arah atau jalan dengan median faktor koreksi pembagian arah jalan adalah 1,0.

Tabel3.FaktorPenyesuaianKapasitasAkibatPem bagianArah $\left(\mathrm{FC}_{\mathrm{SP}}\right)$

\begin{tabular}{|c|c|c|c|c|c|c|}
\hline \multicolumn{2}{|c|}{$\begin{array}{c}\text { Pemisah arah SP } \\
(\%-\%)\end{array}$} & $\begin{array}{c}50- \\
50\end{array}$ & $55-45$ & $\begin{array}{c}60- \\
40\end{array}$ & $\begin{array}{c}65- \\
35\end{array}$ & $\begin{array}{c}70- \\
30\end{array}$ \\
\hline \multirow{3}{*}{$\mathrm{FC}_{\mathrm{SP}}$} & $\begin{array}{c}\text { Dua- } \\
\text { lajur(2/2) }\end{array}$ & 1,00 & 0,97 & 0,94 & 0,91 & 0,88 \\
\cline { 2 - 7 } & $\begin{array}{c}\text { Empat- } \\
\text { lajur (4/2) }\end{array}$ & 1,00 & 0,985 & 0,97 & 0,955 & 0,94 \\
\hline
\end{tabular}

Faktor penyesuaian kapasitas akibat hambatan samping untuk ruas jalan yang mempunyai kereb didasarkan pada 2 faktor yaitu lebar kerb dan kelas hambatan samping.Nilai faktor penyesuaian kapasitas akibat hambatan samping ini dapat dilihat pada Tabel berikut:

Tabel4.FaktorPenyesuaianKapasitasAkibatHam batanSamping $\left(\mathrm{FC}_{\mathrm{SF}}\right)$

\begin{tabular}{|c|c|c|c|c|c|}
\hline \multirow[t]{3}{*}{$\begin{array}{l}\text { Tipe } \\
\text { jalan }\end{array}$} & \multirow[t]{3}{*}{$\begin{array}{c}\text { Kelas } \\
\text { hambatan } \\
\text { samping }\end{array}$} & \multirow{2}{*}{\multicolumn{4}{|c|}{$\begin{array}{l}\text { Faktor penyesuaian untuk hambatan } \\
\text { samping dan jarak kerb penghalang } \\
\left(\mathrm{FC}_{\mathrm{SF}}\right)\end{array}$}} \\
\hline & & & & & \\
\hline & & $\leq 0,5$ & 1,0 & 1,5 & $\geq 2,0$ \\
\hline \multirow[t]{5}{*}{$4 / 2 \mathrm{D}$} & VL & 0,95 & 0.97 & 0.99 & 1.01 \\
\hline & $\mathrm{L}$ & 0.94 & 0.96 & 0.98 & 1.00 \\
\hline & M & 0.91 & 0.93 & 0.95 & 0.98 \\
\hline & $\mathrm{H}$ & 0.86 & 0.89 & 0.92 & 0.95 \\
\hline & $\mathrm{VH}$ & 0.81 & 0.85 & 0.88 & 0.92 \\
\hline \multirow[t]{5}{*}{ 4/2 UD } & VL & 0.95 & 0.97 & 0.99 & 1.01 \\
\hline & $\mathrm{L}$ & 0.93 & 0.95 & 0.97 & 1.00 \\
\hline & M & 0.90 & 0.92 & 0.95 & 0.97 \\
\hline & $\mathrm{H}$ & 0.84 & 0.87 & 0.90 & 0.93 \\
\hline & VH & 0.77 & 0.81 & 0.85 & 0.90 \\
\hline \multirow{5}{*}{$\begin{array}{c}2 / 2 \mathrm{U} \\
\text { atau } \\
\text { Jalan } \\
\text { satu-arah } \\
\text { D }\end{array}$} & VL & 0.93 & 0.95 & 0.97 & 0.99 \\
\hline & $\mathrm{L}$ & 0.90 & 0.92 & 0.95 & 0.97 \\
\hline & M & 0.86 & 0.88 & 0.91 & 0.94 \\
\hline & $\mathrm{H}$ & 0.78 & 0.81 & 0.84 & 0.88 \\
\hline & $\mathrm{VH}$ & 0.68 & 0.72 & 0.77 & 0.82 \\
\hline
\end{tabular}

Faktor penyesuaian ukuran kota didasarkan pada jumlah penduduk, faktorpenyesuaian ukuran kota dapat dilihat pada tabel berikut: 
Tabel5.FaktorPenyesuaianUkuran $\operatorname{Kota}\left(\mathbf{F C}_{\mathrm{CS}}\right)$

\begin{tabular}{|c|c|}
\hline $\begin{array}{c}\text { Ukuran kota } \\
\text { juta penduduk) }\end{array}$ & $\begin{array}{c}\text { Faktor penyesuaian } \\
\text { untuk ukuran kota }\end{array}$ \\
\hline$<0,1$ & 0,86 \\
\hline $0,1-0,5$ & 0,90 \\
\hline $0,5-1,0$ & 0,94 \\
\hline $1,0-3,0$ & 1,00 \\
\hline$>3,0$ & 1,04 \\
\hline
\end{tabular}

b. Derajat Kejenuhan (DS)

Derajat kejenuhan (DS) didefinisikan sebagai rasio arus jalan terhadap kapasitas,yang digunakan sebagai faktor utama dalam penentuan tingkat kinerja simpang dan segmen jalanPersamaan dasar untuk menentukan derajat kejenuhan adalah sebagai berikut:

$$
D S=\frac{V}{C}
$$

dengan :

DS = Derajat kejenuhan

$\mathrm{V}=$ Volume Arus lalu lintas (smp/jam)

$\mathrm{C}=$ Kapasitas (smp/jam)

c. KecepatanArus Bebas

Persamaan untuk penentuan kecepatan arus bebas mempunyai bentuk umum berikut:

$$
F V=\left(F V_{O}+F V_{W}\right) \cdot F F V_{S F} \cdot F F V_{C S}
$$

dengan :

$\mathrm{FV}=$ Kecepatan arus bebas kendaraan ringan pada kondisi lapangan $(\mathrm{km} / \mathrm{jam})$.

$\mathrm{FV}_{0}=$ Kecepatan arus bebas dasar kendaraan ringan pada jalan yang diamati(km/jam).

$\mathrm{FV}_{\mathrm{W}}=$ Penyesuaian kecepatan untuk lebar jalan $(\mathrm{km} / \mathrm{jam})$.

$\mathrm{FFV}_{\mathrm{SF}}=$ Faktor penyesuaian akibat hambatan samping dan lebar bahu.

$\mathrm{FFV}_{\mathrm{CS}}=$ Faktor penyesuaian ukuran kota

d. KecepatanTempuh

MKJI 1997 menggunakan kecepatan tempuh sebagai ukuran utama kinerja segmen jalan, karena mudah dimengerti dan diukur, dan merupakan masukan yang penting untuk biaya pemakai jalan dalam analisis ekonomi. Kecepatan tempuh ditentukan dengan menggunakan grafik pada gambar berikut :

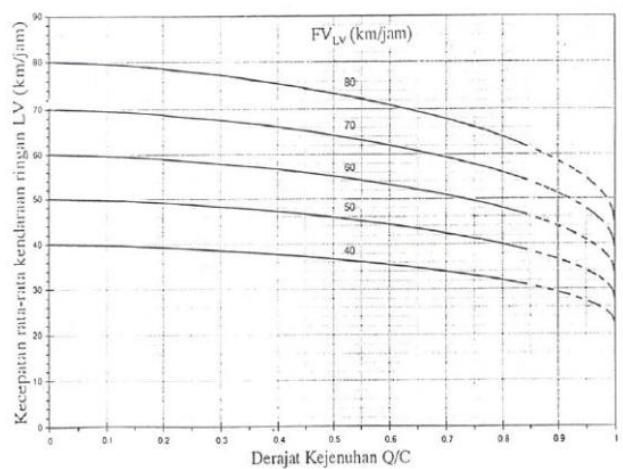

Gambar 1. Kecepatan sebagai fungsi DS untuk jalan banyak lajur dan satu Arah

e. Tingkat Pelayanan Jalan (Level Of Service) Menurut Hendarto (2001), tingkat pelayanan menggambarkan kondisi operasional arus lalu lintas dan persepsi pengendara dalam terminologi kecepatan, waktu tempuh, kenyamanan berkendaraan, kebebasan bergerak, gangguan arus lalu lintas lainnya, keamanan, dan keselamatan.Nilai tingkat pelayanan jalan (level of service) dapat dilihat pada tabel berikut.

Tabel 6.Nilai Tingkat PelayananJalan

\begin{tabular}{|c|c|c|c|l|}
\hline No & $\begin{array}{c}\text { Tingkat } \\
\text { Pelayanan }\end{array}$ & $\mathbf{D}=\mathbf{V} / \mathbf{C}$ & $\begin{array}{c}\text { Kecepatan } \\
\text { Ideal } \\
\text { (km/jam) }\end{array}$ & $\begin{array}{c}\text { Kondisi/Keadaan } \\
\text { Lalu Lintas }\end{array}$ \\
\hline 1 & A & $<0,04$ & $>60$ & $\begin{array}{l}\text { Lalu lintas } \\
\text { lengang, } \\
\text { kecepatan bebas }\end{array}$ \\
\hline 2 & B & $0,04-0,24$ & $50-60$ & $\begin{array}{l}\text { Lalu lintas agak } \\
\text { ramai, kecepatan } \\
\text { menurun }\end{array}$ \\
\hline 3 & C & $0,25-0,54$ & $40-50$ & $\begin{array}{l}\text { Lalu lintas ramai, } \\
\text { kecepatan terbatas }\end{array}$ \\
\hline 4 & D & $0,55-0,80$ & $35-40$ & $\begin{array}{l}\text { Lalu lintas jenuh, } \\
\text { kecepatan mulai } \\
\text { rendah }\end{array}$ \\
\hline 5 & E & $0,81-1,00$ & $30-35$ & $\begin{array}{l}\text { Lalu lintas mulai } \\
\text { macet, kecepatan } \\
\text { rendah }\end{array}$ \\
\hline 6 & F & $>1,00$ & $<30$ & $\begin{array}{l}\text { Lalu lintas macet, } \\
\text { kecepatan rendah } \\
\text { sekali }\end{array}$ \\
\hline
\end{tabular}

Sumber: Highway Capacity Manual, (2000)

\section{HASILDAN PEMBAHASAN}

3.1 DataKarakteristik Jalan

Supermarket Pagar Alam Square berada di Jalan Indragiri. Berikut data jalan:

1. Lebar Jalan : 10 meter 
2. Lebar Trotoar : 1 meter

3. Jumlah Jalur : satu arah

4. Jumlah Lajur : dua lajur

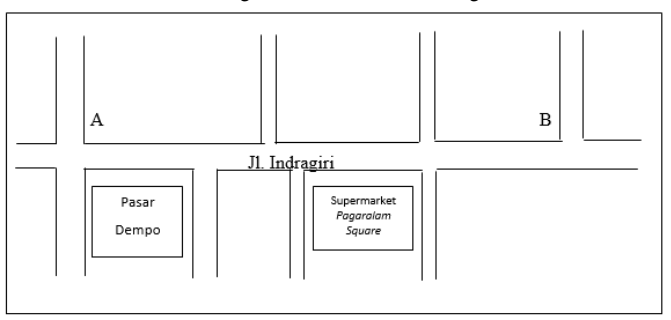

Gambar 2. Denah Lokasi Penelitian

Parkir pada badan jalan di Jalan Indragiri dengan Pola parkir90 ${ }^{\circ}$

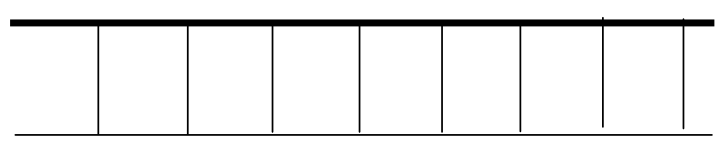

Gambar 2. Lay Out Parkir

\subsection{Analisa Data}

a) KecepatanArusBebas (FV)

Kecepatan arus bebas (FV) di Jalan Indragiri dihitung dengan berikut adalah persamaan bentuk umum dan tabel kecepatan arus.

$$
F V=\left(F V_{O}+F V_{W}\right) \cdot F F V_{S F} \cdot F F V_{C S}
$$

\section{Tabel 7. Kecepatan Arus Bebas (FV)}

\begin{tabular}{|c|l|c|}
\hline No & Faktor Analisa & Nilai \\
\hline 1 & $\begin{array}{l}\text { Kecepatan Arus Bebas Dasar untuk } \\
\text { Jalan Perkotaan }\left(\mathrm{FV}_{0}\right)\end{array}$ & 42 \\
\hline 2 & $\begin{array}{l}\text { Penyesuaian Kecepatan Arus Bebas } \\
\text { Untuk Lebar Jalur Lalu-Lintas (FV }\end{array}$ W $)$ & -3 \\
\hline 3 & $\begin{array}{l}\text { Faktor Penyesuaian Kecepatan Arus } \\
\text { Bebas Untuk Hambatan } \\
\text { Sampingdengan Jarak Kerb } \\
\text { Penghalang (FFV }\end{array}$ & 0,82 \\
\hline 4 & $\begin{array}{l}\text { Faktor Penyesuaian Kecepatan Arus } \\
\text { Bebas untuk Ukuran Kota (FFV }\end{array}$ & 0,93 \\
\hline 5 & Kecepatan Arus Bebas (FV) & 29,7414 \\
\hline
\end{tabular}

b) $\operatorname{Kapasitas}(\mathrm{C})$

Analisis kapasitas ruas jalan dihitung pada hari kerja dan hari libur. Hari kerja diwakili oleh hari Senin dan Kamis, sedangkan hari libur diwakili hari Minggu.Berdasarkan data geometrik dan data kondisi lingkungan ruas jalan yang didapat dari hasil survey di wilayah studi, maka diperoleh nilai-nilai $\mathrm{C}_{0}, \mathrm{Fcw}, \mathrm{FCsp}$, FCsf, FCcs. Berdasarkan data-data, maka diperoleh nilai kapasitas ruas jalan seperti tertera pada Tabel berikut.

Tabel 8. Kapasitas Jalan Dengan Pengurangan Lebar Jalur Lalu Lintas Efektif Pada Hari Senin, 04 Agustus 2014

\begin{tabular}{|c|l|c|}
\hline No & \multicolumn{1}{|c|}{ Faktor Analisa } & Nilai \\
\hline 1 & $\begin{array}{l}\text { Kapasitas Dasar (Co) } \\
\text { (smp/jam) }\end{array}$ & 2900 \\
\hline 2 & $\begin{array}{l}\text { Faktor Penyesuaian } \\
\text { Lebar Jalur (FCw) }\end{array}$ & 0,87 \\
\hline 3 & $\begin{array}{l}\text { Faktor Penyesuaian } \\
\text { Pemisah Arah (FCsp) }\end{array}$ & 0,90 \\
\hline 4 & $\begin{array}{l}\text { Faktor Penyesuaian } \\
\text { Hambatan Samping } \\
\text { FCsf) }\end{array}$ & 0,86 \\
\hline 5 & $\begin{array}{l}\text { Faktor Penyesuaian } \\
\text { Ukuran Kota (FCcs) }\end{array}$ & 2043,63 \\
\hline 6 & Kapasitas (C) (smp/jam) \\
\hline
\end{tabular}

Tabel 9. Kapasitas Jalan Dengan Pengurangan Lebar Jalur Lalu Lintas Efektif Pada Hari Kamis, 07 Agustus 2014

\begin{tabular}{|c|l|c|}
\hline No & \multicolumn{1}{|c|}{ Faktor Analisa } & Nilai \\
\hline 1 & $\begin{array}{l}\text { Kapasitas Dasar (Co) } \\
\text { (smp/jam) }\end{array}$ & 2900 \\
\hline 2 & $\begin{array}{l}\text { Faktor Penyesuaian } \\
\text { Lebar Jalur (FCw) }\end{array}$ & 0,87 \\
\hline 3 & $\begin{array}{l}\text { Faktor Penyesuaian } \\
\text { Pemisah Arah (FCsp) }\end{array}$ & 0,90 \\
\hline 4 & $\begin{array}{l}\text { Faktor Penyesuaian } \\
\text { Hambatan Samping } \\
\text { (FCsf) }\end{array}$ & 0,86 \\
\hline 5 & $\begin{array}{l}\text { Faktor Penyesuaian } \\
\text { Ukuran Kota (FCcs) }\end{array}$ & 2043,63 \\
\hline 6 & Kapasitas (C) (smp/jam) \\
\hline
\end{tabular}

Tabel 10. Kapasitas Jalan Dengan Pengurangan Lebar Jalur Lalu Lintas Efektif Pada Hari Minggu, 10 Agustus 2014

\begin{tabular}{|c|l|c|}
\hline No & \multicolumn{1}{|c|}{ Faktor Analisa } & Nilai \\
\hline 1 & $\begin{array}{l}\text { Kapasitas Dasar (Co) } \\
\text { (smp/jam) }\end{array}$ & 2900 \\
\hline 2 & $\begin{array}{l}\text { Faktor Penyesuaian } \\
\text { Lebar Jalur (FCw) }\end{array}$ & 0,87 \\
\hline 3 & $\begin{array}{l}\text { Faktor Penyesuaian } \\
\text { Pemisah Arah (FCsp) }\end{array}$ & 0,90 \\
\hline 4 & $\begin{array}{l}\text { Faktor Penyesuaian } \\
\text { Hambatan Samping } \\
\text { (FCsf) }\end{array}$ & 0,86 \\
\hline 5 & $\begin{array}{l}\text { Faktor Penyesuaian } \\
\text { Ukuran Kota (FCcs) }\end{array}$ & 2043,63 \\
\hline 6 & Kapasitas (C) (smp/jam) \\
\hline
\end{tabular}

Kapasitas jalan dengan pengurangan lebar jalur lalu lintas efektif sebesar 4 meter.Kapasitas ruas jalan pada hari kerja maupun hari libur adalah sama. Hambatan 
samping berbobot yang berbeda tetapi masih termasuk dalam kelas hambatan samping yang sama yaitu dikategorikan sangat tinggi,karena jalan ini merupakan daerah komersil dengan aktivitas pasar berada di pinggir jalan.Kapasitas dasar yang diperoleh ditentukan berdasarkan jumlah lajur dan jumlah jalur jalan Indragiri merupakan jalan 2 lajur 2 arah tak terbagi dengan kapastias dasar $\left(\mathrm{C}_{0}\right)=2900 \mathrm{smp} / \mathrm{jam}$ total dua arah.

c) DerajatKejenuhan (DS)

Nilai derajat kejenuhan (V/C ratio) untuk hari Senin, Kamis dan Minggudilihat berdasarkan dampak parkir pada badan jalan (on street parking) terhadap tingkat pelayanan jalan sesuai standar Highway Capacity Manual 2000 (HCM 2000). Berikut adalah tabel nilai tingkat pelayanan jalan.

Tabel 11. Nilai Tingkat Pelayanan Jalan Hari Senin, 04 Agustus 2014

\begin{tabular}{|c|c|c|c|c|}
\hline No & Pukul & $\begin{array}{c}\text { Derajat } \\
\text { Kejenuh } \\
\text { an } \\
\end{array}$ & $\begin{array}{c}\text { Tingkat } \\
\text { Pelayanan }\end{array}$ & $\begin{array}{l}\text { Kondisi Lalu } \\
\text { Lintas }\end{array}$ \\
\hline 1 & $\begin{array}{l}07.00- \\
08.00\end{array}$ & 0,1383 & B & $\begin{array}{l}\text { Lalu lintas agak } \\
\text { ramai, kecepatan } \\
\text { menurun }\end{array}$ \\
\hline 2 & $\begin{array}{l}08.00- \\
09.00\end{array}$ & 0,1040 & B & $\begin{array}{l}\text { Lalu lintas agak } \\
\text { ramai, kecepatan } \\
\text { menurun }\end{array}$ \\
\hline 3 & $\begin{array}{c}09.00- \\
10.00\end{array}$ & 0,1297 & B & $\begin{array}{l}\text { Lalu lintas agak } \\
\text { ramai, kecepatan } \\
\text { menurun }\end{array}$ \\
\hline 4 & $\begin{array}{l}10.00- \\
11.00\end{array}$ & 0,1566 & B & $\begin{array}{l}\text { Lalu lintas agak } \\
\text { ramai, kecepatan } \\
\text { menurun }\end{array}$ \\
\hline 5 & $\begin{array}{l}11.00- \\
12.00\end{array}$ & 0,1620 & B & $\begin{array}{l}\text { Lalu lintas agak } \\
\text { ramai, kecepatan } \\
\text { menurun }\end{array}$ \\
\hline 6 & $\begin{array}{l}12.00- \\
13.00\end{array}$ & 0,2485 & $\mathrm{C}$ & $\begin{array}{l}\text { Lalu lintas } \\
\text { ramai, kecepatan } \\
\text { terbatas }\end{array}$ \\
\hline 7 & $\begin{array}{l}13.00- \\
14.00\end{array}$ & 0,2425 & $\mathrm{C}$ & $\begin{array}{l}\text { Lalu lintas } \\
\text { ramai, kecepatan } \\
\text { terbatas }\end{array}$ \\
\hline 8 & $\begin{array}{l}14.00- \\
15.00\end{array}$ & 0,1524 & B & $\begin{array}{l}\text { Lalu lintas agak } \\
\text { ramai, kecepatan } \\
\text { menurun }\end{array}$ \\
\hline 9 & $\begin{array}{c}15.00- \\
16.00\end{array}$ & 0,2657 & $\mathrm{C}$ & $\begin{array}{l}\text { Lalu lintas } \\
\text { ramai, kecepatan } \\
\text { terbatas }\end{array}$ \\
\hline 10 & $\begin{array}{l}16.00- \\
17.00\end{array}$ & 0,5191 & $\mathrm{C}$ & $\begin{array}{l}\text { Lalu lintas } \\
\text { ramai, kecepatan } \\
\text { terbatas }\end{array}$ \\
\hline 11 & $\begin{array}{l}17.00- \\
18.00\end{array}$ & 0,3725 & $\mathrm{C}$ & $\begin{array}{l}\text { Lalu lintas } \\
\text { ramai, kecepatan } \\
\text { terbatas }\end{array}$ \\
\hline
\end{tabular}

Tabel 12. Nilai Tingkat Pelayanan Jalan Hari Senin, 07Agustus 2014

\begin{tabular}{|c|c|c|c|c|}
\hline No & Pukul & $\begin{array}{c}\text { Derajat } \\
\text { Kejenuhan }\end{array}$ & $\begin{array}{c}\text { Tingkat } \\
\text { Pelayanan }\end{array}$ & $\begin{array}{c}\text { Kondisi Lalu } \\
\text { Lintas }\end{array}$ \\
\hline 1 & $\begin{array}{c}07.00- \\
08.00\end{array}$ & 0.1451 & B & $\begin{array}{l}\text { Lalu lintas agak } \\
\text { ramai, kecepatan } \\
\text { menurun }\end{array}$ \\
\hline 2 & $\begin{array}{c}08.00- \\
09.00\end{array}$ & 0.1016 & B & $\begin{array}{l}\text { Lalu lintas agak } \\
\text { ramai, kecepatan } \\
\text { menurun }\end{array}$ \\
\hline 3 & $\begin{array}{c}09.00- \\
10.00\end{array}$ & 0.1202 & B & $\begin{array}{l}\text { Lalu lintas agak } \\
\text { ramai, kecepatan } \\
\text { menurun }\end{array}$ \\
\hline 4 & $\begin{array}{l}10.00- \\
11.00\end{array}$ & 0.1554 & B & $\begin{array}{l}\text { Lalu lintas agak } \\
\text { ramai, kecepatan } \\
\text { menurun }\end{array}$ \\
\hline 5 & $\begin{array}{l}11.00- \\
12.00\end{array}$ & 0.1755 & B & $\begin{array}{l}\text { Lalu lintas agak } \\
\text { ramai, kecepatan } \\
\text { menurun }\end{array}$ \\
\hline 6 & $\begin{array}{l}12.00- \\
13.00\end{array}$ & 0.2425 & $\mathrm{C}$ & $\begin{array}{l}\text { Lalu lintas } \\
\text { ramai, kecepatan } \\
\text { terbatas }\end{array}$ \\
\hline 7 & $\begin{array}{l}13.00- \\
14.00\end{array}$ & 0.2498 & $\mathrm{C}$ & $\begin{array}{l}\text { Lalu lintas } \\
\text { ramai, kecepatan } \\
\text { terbatas }\end{array}$ \\
\hline 8 & $\begin{array}{l}14.00- \\
15.00\end{array}$ & 0.1644 & B & $\begin{array}{l}\text { Lalu lintas agak } \\
\text { ramai, kecepatan } \\
\text { menurun }\end{array}$ \\
\hline 9 & $\begin{array}{l}15.00- \\
16.00\end{array}$ & 0.2616 & $\mathrm{C}$ & $\begin{array}{l}\text { Lalu lintas } \\
\text { ramai, kecepatan } \\
\text { terbatas }\end{array}$ \\
\hline 10 & $\begin{array}{l}16.00- \\
17.00\end{array}$ & 0.5207 & $\mathrm{C}$ & $\begin{array}{l}\text { Lalu lintas } \\
\text { ramai, kecepatan } \\
\text { terbatas }\end{array}$ \\
\hline 11 & $\begin{array}{l}17.00- \\
18.00\end{array}$ & 0.3379 & $\mathrm{C}$ & $\begin{array}{l}\text { Lalu lintas } \\
\text { ramai, kecepatan } \\
\text { terbatas }\end{array}$ \\
\hline
\end{tabular}

Tabel 13. Nilai Tingkat Pelayanan Jalan Hari Senin, 10 Agustus 2014

\begin{tabular}{|c|c|c|c|l|}
\hline No & Pukul & $\begin{array}{c}\text { Derajat } \\
\text { Kejenuh } \\
\text { an }\end{array}$ & $\begin{array}{c}\text { Tingkat } \\
\text { Pelayan } \\
\text { an }\end{array}$ & \multicolumn{1}{|c|}{$\begin{array}{c}\text { Kondisi Lalu } \\
\text { Lintas }\end{array}$} \\
\hline 1 & $\begin{array}{c}07.00- \\
08.00\end{array}$ & 0.0842 & B & $\begin{array}{l}\text { Lalu lintas agak } \\
\text { ramai, kecepatan } \\
\text { menurun }\end{array}$ \\
\hline 2 & $\begin{array}{c}08.00- \\
09.00\end{array}$ & 0.0991 & B & $\begin{array}{l}\text { Lalu lintas agak } \\
\text { ramai, kecepatan } \\
\text { menurun }\end{array}$ \\
\hline 3 & $\begin{array}{c}09.00- \\
10.00\end{array}$ & 0.1151 & B & $\begin{array}{l}\text { Lalu lintas agak } \\
\text { ramai, kecepatan } \\
\text { menurun }\end{array}$ \\
\hline 4 & $\begin{array}{c}10.00- \\
11.00\end{array}$ & 0.1360 & B & $\begin{array}{l}\text { Lalu lintas agak } \\
\text { ramai, kecepatan } \\
\text { menurun }\end{array}$ \\
\hline 5 & $\begin{array}{c}11.00- \\
12.00\end{array}$ & 0.1382 & B & $\begin{array}{l}\text { Lalu lintas agak } \\
\text { ramai, kecepatan } \\
\text { menurun }\end{array}$ \\
\hline 6 & $\begin{array}{c}12.00- \\
13.00\end{array}$ & 0.1719 & B & $\begin{array}{l}\text { Lalu lintas agak } \\
\text { ramai, kecepatan } \\
\text { menurun }\end{array}$ \\
\hline 7 & $13.00-$ & 0.2226 & B & Lalu lintas agak \\
\hline
\end{tabular}




\begin{tabular}{|c|c|c|c|l|}
\hline & 14.00 & & & $\begin{array}{l}\text { ramai, kecepatan } \\
\text { menurun }\end{array}$ \\
\hline 8 & $\begin{array}{c}14.00- \\
15.00\end{array}$ & 0.1494 & $\mathrm{~B}$ & $\begin{array}{l}\text { Lalu lintas agak } \\
\text { ramai, kecepatan } \\
\text { menurun }\end{array}$ \\
\hline 9 & $\begin{array}{c}15.00- \\
16.00\end{array}$ & 0.1627 & $\mathrm{~B}$ & $\begin{array}{l}\text { Lalu lintas agak } \\
\text { ramai, kecepatan } \\
\text { menurun }\end{array}$ \\
\hline 10 & $\begin{array}{c}16.00- \\
17.00\end{array}$ & 0.3120 & $\mathrm{C}$ & $\begin{array}{l}\text { Lalu lintas } \\
\text { ramai, kecepatan } \\
\text { terbatas }\end{array}$ \\
\hline 11 & $\begin{array}{c}17.00- \\
18.00\end{array}$ & 0.2865 & $\mathrm{C}$ & $\begin{array}{l}\text { Lalu lintas } \\
\text { ramai, kecepatan } \\
\text { terbatas }\end{array}$ \\
\hline
\end{tabular}

\section{SIMPULAN}

Berdasarkan hasil analisis pengaruh kegiatan perparkiran pada badan jalan (on street parking) diruas Jalan Indragiri depan Supermarket Pagaralam square menyebabkan berkurangnya lebar jalur lalu lintas efektif sampai sebesar 4 meter sehingga terjadi penurunan kapasitas ruas, baik pada hari kerja maupun pada hari libur.

Derajat Kejenuhan tinggi pada saat volume meningkat sekaligus pada saat kapasitas ruas jalan berkurang dikarenakan adanya badan jalan yang difungsikan sebagai areal parkir. Hal ini dapat dilihat pada hari kerja yaitu hari Senin dan hari kamis. Pada hari libur yaitu hari Minggu terjadi penurunan angka derajat kejenuhan. Hal ini menunjukkan bahwa rendahnya angka derajat kejenuhan disebabkan rendahnya volume lalu lintas sekaligus meningkatnya kapasitas ruas jalan karena hampir tidak ada atau hanya sedikit kendaraan yang parkir pada badan jalan.

\section{DAFTAR RUJUKAN}

Direktorat Jendral Bina Marga, Manual Kapasitas Jalan Indonesia (MKJI), Sweroaddan PT. Bina Karya, Jakarta, 1997.

Nasution. H. M. N, 1996, Manajemen Transportasi, Penerbit Ghalia Indonesia.

PP Tentang Jalan Nomor 34 Tahun 2006, PERMEN PU NO.03/PRT/M/2012

Sukirman, Silvia. 1998. Dasar - Dasar Perencanaan Geometrik Jalan. Bandung: Nova

Undang - Undang Republik Indonesia Nomor 38 Tahun 2004 Tentang Jalan 